\title{
Family Firms Can Perform Better by Overcoming Strategic Unwillingness: Implications of "Familiness" for Coopetition Strategy
}

\author{
Steve Kyungjae Lee ${ }^{1}$ \\ ${ }^{1}$ College of Business Administration, Chung-Ang University, Seoul, Republic of Korea \\ Correspondence: Steve Kyungjae Lee, College of Business Administration, Chung-Ang University, 310 Management \\ Building 84 Heukseok-ro, Dongjak-gu, Seoul 06974, Korea. Tel: 82-2-820-5539.
}

Received: May 2, 2021 Accepted: June 7, 2021 Online Published: June 18, 2021

doi:10.5430/jbar.v10n2p1 URL: https://doi.org/10.5430/jbar.v10n2p1

\begin{abstract}
This study discusses the primary characteristics of family firms in implementing strategic decisions and the fundamental nature of coopetition. In this context, we provide a rather ironic perspective that has not been discussed in prior studies. Family firms prioritize the preservation of socioemotional wealth rather than seeking economic benefits when making strategic choices, explaining their unwillingness to engage in coopetition strategies. However, these strategic features enable family firms to implement coopetition strategies more successfully than other types of firms. This is because they demonstrate a lower risk of opportunistic behavior, driven by the pursuit of self-interest rather than collective benefits. This study provides valuable insights and implications by associating the unique characteristics of family firms in implementing strategic decisions with the likelihood and stability of coopetition.
\end{abstract}

Keywords: family firms, coopetition, socioemotional wealth, strategic decision-making, opportunistic behavior

\section{Introduction}

Prior studies have been interested in coopetition - that is, the cooperation between competitors - rather than focusing on the dichotomy between cooperation and competition in inter-firm relationships. In this context, partners compete in certain value-chain areas, such as marketing and sales, and product markets while cooperating in other areas, such as research and development (R\&D) and product markets. Studies show that firms cooperate with competitors for efficient resource exploitation (Ritala, Golnam, \& Wegmann, 2014), protection against knowledge leakage (Choi, Garcia, \& Friedrich, 2010), innovation through collective R\&D activities (Gnyawali \& Park, 2011), industrial standards battles for technological dominance (Luo, 2007), and cost-sharing decisions related to marketing (Oum, Park, Kim, \& Yu, 2004). Moreover, prior studies demonstrated that coopetition can be a beneficial strategy for firms (Gnyawali \& Park, 2011) in terms of increasing their market share (Meade, Hyman, \& Blank, 2009), improving corporate performance (Robert, Marques, \& Le Roy, 2009), and creating new technologies and products (Bouncken, Clauß, \& Fredrich, 2016). Due to the critical benefits of coopetition, competitors, who are firms in the same industry, undertake over $50 \%$ of the inter-firm collaborations (Gnyawali, Madhavan, He, \& Bengtsson, 2016; Gnyawali \& Park, 2011).

Despite extensive research on this topic, however, much coopetition research has been limited in terms of research contexts. According to the recent systematic review by coopetition scholars (e.g., Devece, Ribeiro-Soriano, \& Palacios-Marqués, 2019; Lascaux, 2020), coopetition has been limited in exploring a greater variety of firms, which leads to less understanding of the coopetition in the wider context of entrepreneurship (e.g., family firms, start-ups or small and medium-sized enterprise). One of the foremost studies in the field of coopetition is that of the coopetition behavior of family firms. Family firms are the oldest and most common form of business organization, playing a significant role in the employment and economic activities of many countries (Andersson, Johansson, Karlsson, Lodefalk, \& Poldahl, 2018). However, we lack complete understanding of the implications of "familiness" in coopetition-based strategy. This study attempts to associate coopetition, whose strategic importance has been increasing recently, with family firms, the most common type of firms that play an important role in economic activities. Specifically, this study discusses the primary characteristics of family firms, especially in strategic decision-making, as opposed to their non-family counterparts. It also scrutinizes the distinctive nature of coopetition in contrast with the general types of inter-firm collaborations. Therefore, based on the fundamental understanding of the nature of family firms and coopetition, we theoretically investigate the unique characteristics of family firms in 
implementing strategic decisions with the likelihood and stability of coopetition.

Our study attempts to answer the following research questions.

First, we question how the unique characteristics of family firms in implementing strategic decisions affect coopetition activities - that is, whether family firms are more active or passive toward coopetition engagement than non-family firms.

Second, we question how the unique characteristics of family firms in implementing strategic decisions can affect the stability and, therefore, the success of coopetition while implementing coopetition-based strategies.

Third, we question what important implications we may obtain in the field of coopetition research, management, and policy with respect to our valuable insights from the previous questions.

This study suggests that family firms are passive in coopetition because of their essential characteristics in terms of strategic decision-making. However, although family firms exhibit a stronger resistance to their engagement in coopetition than non-family firms, this study strongly views family firms as having the qualities of conducting coopetition in a more stable and successful way. Therefore, family firms do not support coopetition; however, if they engage in coopetition, they can perform better than other types of firms. In this regard, this study provides novel, but rather ironic perspective and valuable implications for managers, policymakers, and researchers in support of coopetition.

\section{Understanding the Features and Nature of Family Firms and Coopetition Strategies}

Although family firms are the oldest and most common form of businesses globally, prior studies have focused primarily on publicly traded companies with great ownership dispersion while studying the strategic behavior of firms. This is similar to the study of strategic behavior of firms in relation to coopetition strategy, which provides a limited understanding of coopetition occurring in various types of companies (Devece et al., 2019; Lascaux, 2020). Therefore, in this section, we first examine the strategic characteristics of family firms and the nature of coopetition before discussing the relationship between them.

\subsection{Univerque Characteristics of Family Firs with respect to Strategic Decision-Making}

For many years, studies have significantly contributed toward providing valuable theoretical insights as well as practical implications for the advancement of family firms in their field of business (Chrisman, Chua, \& Sharma, 2005; Lee, Makri, \& Scandura, 2019; Shukla, Carney, \& Gedajlovic, 2014). Prior studies have demonstrated that there are notable differences between the strategic decisions undertaken by family and non-family firms (Berrone, Cruz, \& Gomez-Mejia, 2012). As a result, family firms exhibit strategic behavior different from their non-family counterparts (Gibb Dyer, 2006; Gomez - Mejia, Makri, \& Kintana, 2010).

The most significant strategic difference lies in the fact that family firms do not place utmost importance on the pursuit of economic profit or efficiency while implementing strategic choices. Instead, their most important driver lies in the preservation of socioemotional wealth (SEW), representing the emotional and non-financial value that family members attach to their firms. Therefore, even if a certain strategic choice results in economic losses, these firms are more likely to implement that strategic decision than non-family firms if it preserves or strengthens their SEW because "family firms are typically motivated by, and committed to, the preservation of their SEW" (Berrone et al., 2012, p. 259). For example, according to Gómez-Mejía, Haynes, Núñez-Nickel, Jacobson and Moyano-Fuentes (2007), family-owned olive mills do not join cooperatives in order to preserve their valued traditional business practices. However, this strategic choice can make their cash flow unstable in the future, negatively affecting their subsequent profits. In addition, to maintain a unique management strategy, family firms are reluctant to replace family executives with outside managers, who possess better competence and personal networks, thereby losing potential opportunities to maximize the firms' economic profit for public shareholders (Bennedsen, Nielsen, Pérez-González, \& Wolfenzon, 2007).

Since preserving SEW is more important to family firms, they value historical traditions and managerial independence. In addition, family firms generally exhibit conservative behavior while making strategic decisions, thereby rejecting significant changes against "standards from the past" (Levinson, 1971, p. 92). This is because family firms do not want to negatively affect the existing SEW. Therefore, family firms exhibit an "SEW loss-aversion" behavior when making strategic choices. Interestingly, strategic behaviors driven by SEW loss aversion often collide with those driven by financial risk aversion. Recalling the example of family-owned olive mills, we observe that the family firms' strategic decision not to join a cooperative in order to preserve traditional management practices may be a good decision in terms of SEW loss aversion, but it is not a good decision for the 
purpose of financial risk aversion. This is because failure to join a cooperative could make the future cash flow of family-owned olive mills more volatile, which would increase the subsequent financial risk.

However, there are cases in which the strategic decisions of family firms to avoid SEW losses reduce the company's financial risk and ultimately leave a positive impact on the firms' economic value. For example, Berrone, Cruz, Gomez-Mejia and Larraza-Kintana (2010) empirically demonstrated that family firms are more concerned about environmental issues than non-family firms are because it might help them preserve their family's social reputation in the local community. Although the authors have not provided performance implications, it has been shown that adopting an environmentally friendly management for business practices can contribute toward generating a competitive advantage (Bansal, 2005) and improving firms' long-term financial performance (King \& Lenox, 2002). Nevertheless, empirical studies document that family firms may fail to fully exploit existing economic opportunities, potentially because they follow non-economic goals rather than pursuing economic profit (Feldman, Amit, \& Villalonga, 2016).

The second strategic feature of family firms is that they have a long-term orientation in making strategic choices. One of the advantages shared by family firms is that their executives are often family members who can enjoy the benefit of job security, unlike the executives of non-family companies. Executive members enjoying high job security are more likely to have a long-term perspective while making strategic choices than those who do not share this advantage. Moreover, shareholders in the founding family have a long-term orientation compared to external investors (Memili, Fang, Koc, Yildirim-Öktem, \& Sonmez, 2018); thus, hired executives of family firms, who are not members of the founding family, are under less pressure to earn short-term profits than their non-family counterparts. As a result, family firms are seen to be less engaged in corporate divestment, which primarily ensures a rapid turnaround in revenue (Feldman et al., 2016). Instead, they focus more on long-term-oriented strategic actions, such as increasing R\&D activities for competitiveness in the future (Block, 2009), and establishing stable and friendly relationships with employees, suppliers, buyers, and firms in the same industry (Le Breton-Miller \& Miller, 2006).

Hence, the strategic characteristics of family firms can be summarized as follows. First, the preservation of SEW is more important to family firms than the pursuit of economic benefits while making strategic decisions. Second, family firms generally have a long-term orientation when making strategic choices.

\subsection{Unstable and Risky Nature of Coopetition}

Since the business environment has become more complex and unpredictable in recent years, an increasing number of companies have been interested in coopetition-based strategies (Strese, Meuer, Flatten, \& Brettel, 2016). Unlike traditional inter-firm collaborations such as those formed with supplier or customer partners within value-chain activities or those formed with non-competing partners in other industry, coopetition requires partners to cooperate and compete with each other simultaneously (Czachon \& Mucha-Kuś, 2014). While coopetition strategies can be beneficial to firms for obtaining crucial resources, capabilities, and competitive advantage, partners in coopetition encounter greater conflict and risk than collaborating with indirect competitors (Tidstr€om, 2014). In fact, in the real business world, there have been many incidents in which the failure of coopetition was realized by the unplanned termination of coopetitive relationships. Several empirical studies show that inter-firm partnerships are more likely to fail when partners are direct competitors (e.g., Park \& Russo, 1996).

Existing literature on coopetition provides insights into its risky and unstable nature in the context of inter-firm collaboration. Owing to the paradoxical nature of the relationship, Pellegrin-Boucher, Le Roy and Gurău (2013) suggested that firms could face a "dangerous situation" because coopetition inevitably involves a struggle between generating value together for the purpose of collaboration and pursuing their individual competitiveness by appropriating resources and capabilities. Indeed, allowing competing partners to gain access to unique internal resources and capabilities may weaken the focal firm's competitiveness.

In addition, a similar dilemma may occur if partners face a conflict between sharing knowledge with competing partners and protecting their private information, especially since mutual sharing of knowledge is essential for achieving success in coopetition (De Rond \& Bouchikhi, 2004). In such a paradoxical relationship, partners are more likely to engage in a "learning race" in which each partner seeks to hold back their personal knowledge while opportunistically pursuing self-interest goals, thereby generating a vicious circle that weakens the cooperative relation (Bouncken \& Kraus, 2013). Coopetition can even cause firms to face more serious problem related to the lack of harmony between partners. (Raza-Ullah, Bengtsson, \& Kock, 2014). For instance, when coopetition arises through the formation of a new legal entity such as joint-venture (JV), the organizational culture in the new JV can be multifaceted and contested such that dissimilar cultures can directly collide with each other. To the extent that 
dissimilar cultures are found in different partners, they lead to separate sub-cultures, hindering the integration of partners (Klimas, 2016).

Therefore, coopetition is a "double-edged sword" (Bouncken \& Fredrich, 2012, p. 2060) that is characterized by increased inter-firm risks and conflicts despite its potential benefits to the firm's innovation, performance, and competition. Due to the paradoxical nature of coopetition, where today's allies can easily turn into tomorrow's enemies (Hergert \& Morris, 1988), coopetition can affect the competitive positions of participating firms, which might lead partners to engage in opportunistic behavior. Therefore, the opportunistic behavior of partners to pursue self-interest rather than collective goals is more likely to occur in coopetition than general collaboration. Thus, coopetition is an unstable and risky inter-firm relationship.

\section{Understanding the Relationship between Family Firms and Coopetition}

In this section, based on the understanding of characteristics of family firms in making strategic decision and unstable nature of coopetition, we theoretically discuss how familiness is connected with the likelihood and stability of coopetition.

\subsection{Family Firms'Strategic Willingness in the context of Coopetition Strategy}

The most important aspect in understanding the relationship between family firms and coopetition is determining how the unique characteristics of family firms undertaking strategic decisions will have an impact on their willingness to engage in coopetition. While prior studies have suggested several critical factors associated with the likelihood of coopetition, such as prior experience (Al - Laham, Amburgey. \& Bates, 2008), technological relatedness (Teo \& Bhattacherjee, 2014), top management team's (TMT) human network (Lee \& Park, 2008), and institutional environment (Hitt, Ahlstrom, Dacin, Levitas, \& Svobodina, 2004), there are no factors with regard to the type of company or ownership structure. Here, we attempt to theoretically comprehend how the unique strategic characteristics of family firms affect their willingness to engage in partnerships with their competitors.

In the case of family firms, under coopetition, partners come together to enjoy the benefits of collective goals while simultaneously competing in the same market. This innovative and unfamiliar strategy is completely different from the traditional strategies of business operation. (Here, when we talk about coopetition, we exclude traditional cartel or implicit-collusion. These kinds of coopetition seek to manipulate free-market prices at the expense of overall buyers' benefit; thus, these traditional types of coopetition are highly monitored and prohibited by regulatory authorities and legal institutions) The dichotomy between cooperation and competition has predominated in traditional inter-firm relationships (Hoffmann, Lavie, Reuer, \& Shipilov, 2018). Since a coopetition strategy is also inconsistent with the typical strategies executed by non-family firms, some of them will reject it as well. Due to organizational inertia, firms are generally more attracted toward the types of business operations that they have employed in the past rather than unfamiliar ones (Kelly \& Amburgey, 1991). Therefore, since coopetition strategy is an unfamiliar business operation to both family and non-family firms, they can act passively about its implementation. However, it is important to understand that family firms will portray a greater resistance to engaging in coopetition-based strategies than non-family firms. This is because, when family firms make a strategic choice, their primary concern includes the preservation of SEW rather than pursuing economic profit or efficiency. Even if a certain strategic choice is beneficial to the family firms' economic profit, they will not execute that strategy if the existing SEW is expected to be negatively affected by it.

Traditionally, family firms prefer closed or isolated and independent business operations to outside partners, unlike their non-family counterparts. Studies on family business suggest that family firms tend to solve business problems on their own rather than seeking the help of external parties (Moores \& Barrett, 2010; Pounder, 2015). For example, to avoid dependence on external parties, such as investors, large suppliers, and customers, family firms exhibit limited debt financing and a reserved attitude toward their openness to external partnerships (Kaysey \& Wallau, 2002). In addition, family firms are relatively more concerned about corporate security and confidentiality and are reluctant to disclose such internal information to external investors and business partners (Chua, Chrisman, \& Sharma, 1999). The lack of opportunities for a company's growth and financial profit resulting from such an isolated and independent aspect of business operations are offset by the conviction of current SEW being fully preserved (Gomez-Mejia, 2019).

Under these circumstances, coopetition strategy, which builds partnerships between competitors in the same market, is more inconsistent with the traditional aspect of business operations that family firms have been performing for a long time. When firms engage in coopetition, their specific internal knowledge and information can be exposed to the external competitors. Moreover, their business operations can be highly dependent on external competitors in 
terms of resources and capabilities (Bengtsson, 2016). Dependence on as well as leakage of information to competing partners heavily undermines the independent and traditional way of business operations valued by family members that do not rely on external partners and prohibits the disclosure of inside information. Thus, although coopetition can increase family firms' economic profit, it is a strategic action that potentially creates the loss of SEW. As family firms consider potential SEW losses incurred by coopetition more important than the potential economic benefit incurred by coopetition, family firms are bound to be passive in coopetition. Therefore, the first proposition of this study is as follows.

Proposition 1: There is a negative relationship between familiness and their engagement in coopetition - that is, the unique characteristics of family firms under strategic decision-making decrease firms' willingness to engage in coopetition strategies.

\subsection{Implication of Familiness for the Stability and Success of Coopetition}

In the 3.1 section, it is suggested that family firms' unique characteristics in strategic decision provides a negative influence on the willingness of family firms to engage in coopetition. However, just because family firms have a stronger resistance to coopetition strategy, it can be inappropriate to judge that they will not be good at coopetition.

The second proposition argues that family firms perform better than other types of firms while implementing coopetition strategies despite being passive about it. This is because the unique strategic characteristics of family firms can have a positive impact on the stability and ultimately lead to the success of coopetition. Specifically, this study strongly suggests that, if family firms perform under coopetition, the risk of its unplanned termination can be reduced because family firms are less likely than other firms to engage in an opportunistic behavior. Studies on coopetition have demonstrated that the critical factor responsible for the unexpected dissolution of coopetitive relationships lies in the high possibility of opportunistic behaviors among partners (Das \& Kumar, 2011; Xue, Yuan, \& Shi, 2016). Opportunistic behavior among partners in a collaboration is more likely to arise when they seek their self-interest rather than collective benefits (Park \& Ungson, 2001). Please note that in the 2.2 section, we learned that in the case of coopetition, the likelihood that partners conduct an opportunistic behavior for the pursuit of their own interest rather than collective goals is much greater than that of general cooperation.

Under such risky and unstable coopetition, family firms tend to behave less opportunistically than non-family firms when engaging in coopetition strategies. The main reason lies in the fact that family firms have a greater strategic incentive to pursue SEW rather than economic benefits while making strategic choices. Since economic benefits are not the foremost consideration in family firms' strategic choices, they will be less likely than non-family firms to engage in opportunistic behaviors for the pursuit of their personal financial profit only. For example, when corporate performance declines, family firms undertake fewer restructuring activities for their short-term profit rebound (Feldman et al., 2016). Moreover, they do not easily close long-standing business relationships with customers, employees, and local stakeholders (Block, 2009; Le Breton-Miller \& Miller, 2006). Therefore, family firms display less opportunistic behavior under coopetition, which has a positive effect on stability and success.

However, it might be possible for family firms to trick a rival partner and act opportunistically under the coopetition process in order to preserve or positively influence their SEW. This study strongly suggests that family firms' opportunistic behavior in pursuit of SEW is unlikely. Once perceived as an opportunist by stakeholders as well as firms in the same industry, family firms may lose their long-term SEW, such as family honor, social reputation, and business legitimacy, that they have preserved for years. Furthermore, the loss of SEW in the long term ultimately endangers their long-term survival. When family firms do not survive, SEW, which is important to family member, also vanishes (Berrone et al., 2012; Stockmans, Lybaert, \& Voordeckers, 2010). Thus, even if an opportunistic behavior preserves or strengthens SEW in the short term, it will inevitably result in greater SEW losses in the mid- to long term. Therefore, family firms are less likely to engage in opportunistic behaviors. Empirical studies have demonstrated that, when making a strategic choice, family firms consider not only current but also potential long-term SEW (Cruz \& Justo, 2017; Gomez-Mejia, Campbell, Martin, Hoskisson, Makri, \& Sirmon, 2014). Therefore, if the long-term loss in SEW due to strategic actions, such as opportunistic behaviors during coopetition, is greater than the short-term gain in SEW, family firms do not implement that strategic choice (Hussinger \& Issah, 2019). Regardless of whether family firms pursue SEW or economic benefit, they engage in less opportunistic behaviors than their non-family counterparts do during the coopetition process, thereby suggesting a positive implication on the stability and success of coopetition strategy.

The second reason that enables family firms to perform well under coopetition strategy is the prevalence of their long-term orientation when making strategic choices. Family firms have a relatively mid- to long-term orientation compared to non-family firms. Specifically, family firms are less pressured to seek short-term profit, which allows 
them to implement strategies with a long-term perspective (Lumpkin, Brigham, \& Moss, 2010). Strategic decisions with a long-term orientation positively influence the stability and success of coopetition. In recent years, coopetition has been occurring more frequently since the external environment has become more complex and technological uncertainty has increased (Bouncken \& Fredrich, 2012; Strese et al., 2016). This is because, when firms' resources and capabilities are limited, coopetition strategy is beneficial for companies to increase their chances of survival by jointly responding to external environmental risks rather than coping with future uncertainties alone (Czakon, Klimas, \& Mariani, 2020). However, in most cases, the outcomes under coopetition formed to minimize the risk of external uncertainty are not realized immediately (Chai, Li, Clauss, \& Tangpong, 2019). For example, when competitors jointly develop new technologies or products, coopetition between R\&D and production is relatively uncertain, and outcomes cannot be quickly realized in the market. In a worst-case scenario, if the newly devised products or technologies are not in line with current laws, institutions, and people's perceptions, coopetition partners will have to develop a new technology based on the negative feedbacks or wait until the laws, institutions, and perceptions change favorably. In this case, the implementation of coopetition takes longer than any other form of inter-firm cooperation. Therefore, partners must develop patience and a long-term orientation. When faced with such a situation, family firms do not give up quickly just because coopetition does not perform well in the short term; they continue to work patiently toward it.

To summarize, due to the unique characteristics of pursuing SEW under strategic choices, family firms are less likely to engage in opportunistic behaviors driven by individual interests. In addition, when making strategic choices, family firms generally have a long-term orientation that enables them to be more favorable to coopetition than non-family firms. It requires a substantial amount of time to achieve uncertain outcomes. Therefore, the second proposition of this study is as follows.

Proposition 2: There exists a positive relationship between familiness and the stability and success under coopetition. Therefore, the unique strategic characteristics of family firms increase their likelihood of success under coopetition by enhancing stability.

\section{Important Implications of Coopetition Strategies}

Through the discussions so far, this study provides a novel, but rather ironic view that although family firms are less likely than non-family firms to conduct a coopetition strategy, they can perform coopetition more successfully than any other companies. What are the valuable messages of this view that has not been presented in both family business and coopetition fields? Management studies is a practical discipline that not only presents valuable insights into research but also helps businesses and policymakers in practice. Therefore, our study extracts the following important implications.

\subsection{Implications for Management}

Although coopetition strategy has a positive influence on the survival and competitive advantage of many companies, family firms have a stronger resistance to this strategic action. This is because family chief executive officers (CEOs) and managers strongly believe that coopetition can damage SEW, which they consider of utmost importance to their business operations.

However, family CEOs and managers need to reduce their unsound psychological resistance to coopetition in order to evaluate its strategic value objectively and in a well-balanced manner. Family firms that have limited opportunities for growth due to a lack of internal resources and capabilities can acquire them from coopetition strategy, thereby increasing their potential for growth. Cooperating with rivals in the same industry helps in sharing similar interests and positions with respect to technologies and markets (Kim \& Parkhe, 2009) due to the presence of similar customer demands and uncertainties. Considering that family firms are often challenged by environmental changes and experience vulnerability because of their independent family-oriented management (Lee, 2006), coopetition will enable competitors to collaborate for essential complementary resources and capabilities, which will be beneficial for all the partners involved (Baumard, 2009). Of course, coopetition-based strategy may lead to a loss of SEW in the short-term, but it is an effective strategy that can provide growth opportunities and enhance the survival rate of family firms, which leads to SEW gain in the long term.

The strategic importance of coopetition activities will gradually increase in the future as the market environment becomes increasingly complex and traditional boundaries of industries fade. However, coopetition is more unstable and riskier than any other form of inter-firm cooperation because there is a greater possibility for partners to display opportunistic behavior. Therefore, the ability to manage coopetition in a more stable and successful way than other firms will be a critical factor in achieving competitive advantage in the future marketplace. Through the reduction of 
strategic resistance to coopetition, family firms not only fully exploit their current economic opportunities but also enhance their long-term SEW.

\begin{tabular}{|l|l|}
\hline Family firms' characteristics in strategic decision & Inherent nature of coopetitive relationship \\
\hline $\begin{array}{c}\text { - Family firms value the preservation of SEW more than } \\
\text { economic interests when making strategic choices. }\end{array}$ & $\begin{array}{l}\text { - Partners engaged in coopetition are both allies and } \\
\text { enemies with each other. }\end{array}$ \\
$\begin{array}{l}\text { - Family firms generally take a long-term view when } \\
\text { making strategic choices. }\end{array}$ & $\begin{array}{l}\text { There is much greater possibility of opportunistic } \\
\text { behavior between partners for personal interests, } \\
\text { not for the community. } \rightarrow \text { The instability of the } \\
\text { relationship is very high }\end{array}$ \\
\hline
\end{tabular}

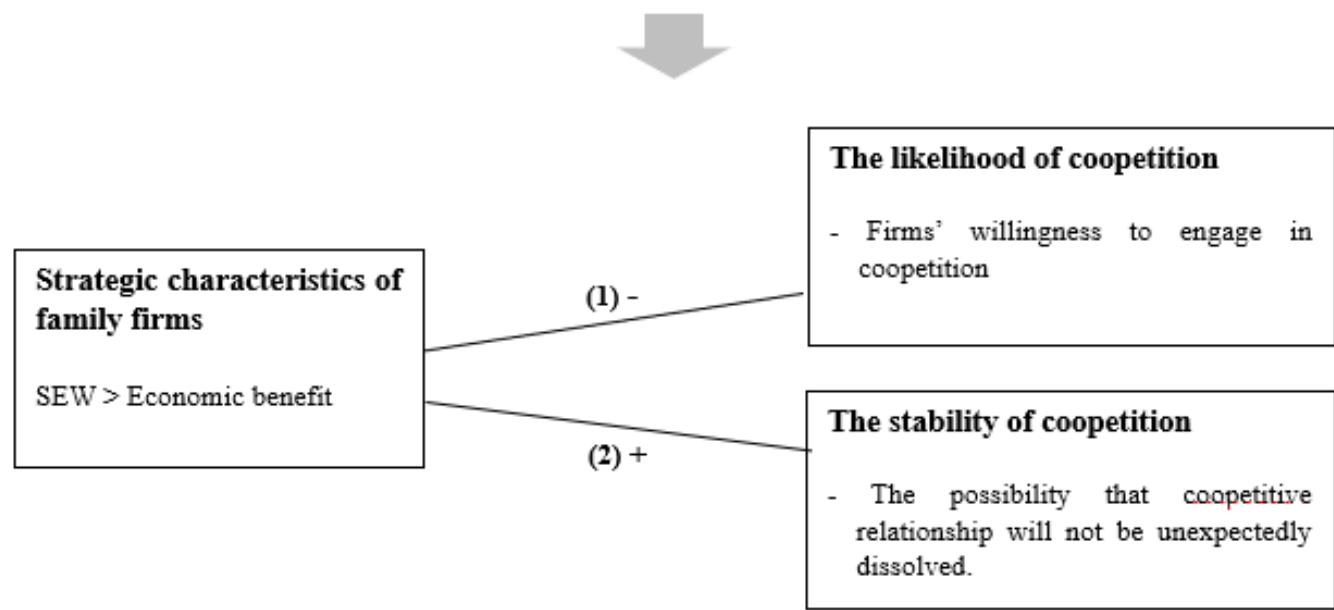

\begin{tabular}{|c|c|c|}
\hline & (1) - & (2) + \\
\hline Mechanism & $\begin{array}{l}\text { - Traditionally, family firms are reluctant to } \\
\text { disclose inside information and prefer an } \\
\text { independent way of operation that does not } \\
\text { rely upon the outside. } \\
\text { - Once engaged in coopetition, information } \\
\text { inside the firm is disclosed to competitors, } \\
\text { which may result in the company being } \\
\text { subordinate to competitors. } \rightarrow \text { Loss of } \\
\text { current SEW } \\
\text { - Thus, family firms are passive in coopetition } \\
\text { because they value the preservation of SEW } \\
\text { more than pursuing economic benefits. }\end{array}$ & $\begin{array}{l}\text { - Family firms do not prioritize pursuing } \\
\text { economic benefits when making strategic } \\
\text { choices. } \rightarrow \text { Possibility of opportunistic } \\
\text { behavior for personal profit is low. } \\
\text { - Opportunistic behavior is also undesirable } \\
\text { on the SEW side, as it leads to greater long- } \\
\text { term SEW losses. } \\
\text { - Family firms have a long-term perspective } \\
\rightarrow \text { Can exhibit patience and consistent } \\
\text { attitude for the obtainment of uncertain } \\
\text { outcomes in coopetition }\end{array}$ \\
\hline
\end{tabular}

Figure 1. A conceptual view on the relationship between familiness and coopetition

\subsection{Implications for Policy}

This study has important implications for industrial policymakers. Currently, the government officials of countries facing economic crises due to low growth are paying great attention to fostering new industries. This is because the more industries those countries foster, the more dynamic the economy and job creation will be, thereby revitalizing the economy (Timmer, Inklaar, O'Mahony, \& Van Ark, 2010). Studies on coopetition have demonstrated that coopetition strategy is useful, especially in fostering new industries with great potential for growth (Bonel \& Rocco, 2007). Moreover, the industries where coopetition is being actively implemented at present do not entail traditional 
industries, such as manufacturing, construction, mining, and energy, but include new high-tech industries, such as IT, bio, and future vehicles (Bouncken, Gast, Kraus, \& Bogers, 2015), which have great potential for growth. Due to the high uncertainty associated with standard technologies and markets in new industries, companies try to mitigate external risks by working together with competitors (Vanyushyn, Bengtsson, Näsholm, \& Boter, 2018).

However, coopetition is more unstable than other types of inter-firm cooperation strategies, which negatively affects the spread of coopetition strategies to foster new industries. Considering that family firms can manage coopetition in a more stable and successful way than other types of companies, government officials provide necessary policies or incentives to family firms such that they can actively engage in coopetition. In addition, government officials need to provide support to alleviate family firms' strong psychological resistance to coopetition strategies. Specifically, government officials need to make it clear to family firms that coopetition can provide new opportunities for their stagnant business and thus ultimately help them strengthen their SEW in the long run.

\subsection{Implications for Research}

Few studies have focused on the coopetition activities of family firms, suggesting that further analyses in this field will be of great academic value in the future. In particular, scholars need to study whether, how and when family firms can make less preferred strategic choices. Answering these research questions can increase our understanding of coopetitive behavior of family firms. For example, it is theoretically valuable to examine whether family firms can make strategic choices that they do not prefer and the process through which they could overcome strategic resistance in order to make that decision. One encouraging news about this research inquiry is that recent family business research, by adopting a mixed-gamble approach, suggests that family firms can engage in strategic actions that they are not willing to take (Hussinger \& Issah, 2019). Specifically, recent studies have shown that family firms not only consider current losses in SEW but also examine potential gains in long-term SEW when making strategic choices (Cruz \& Justo, 2017; Gomez-Mejia et al., 2014). In this situation, if long-term gains are greater than short-term losses in SEW, family firms can make strategic choices that they do not prefer and sufficiently bear short-term SEW losses.

In order to examine the conditions under which family firms are more likely to make strategic choices that they do not prefer, a contingency approach can be beneficial. For example, according to prior studies, organizational inertia weakens and strategic flexibility becomes relatively high when CEOs are recently replaced (Barron, Chulkov, \& Waddell, 2011; Greiner \& Bhambri, 1989), alleviating family firms' long-standing reluctance to engage in coopetition. In addition, when the uncertainty of firms' external environments increases, their participation in strategies that are less preferred may increase (Zacharia, Plasch, Mohan, \& Gerschberger, 2019). Investigating the changes in family firms' strategic willingness to engage in coopetition under various circumstances allows us to better understand the complex strategic behaviors of family firms.

Finally, it should be noted that our conceptual discussion requires empirical support in order to prove its relevance. Therefore, the theoretical relationship between family firms and coopetition suggested in this study needs to be validated through subsequent empirical analyses. Given that secondary data on coopetition activities of family firms are not easily available, questionnaires, case studies, field observations, and experiments can be used to conduct the analyses. Although extending this study through this method would be challenging, it might provide significant insights.

\section{Conclusion}

As technology becomes more complex and the boundaries of traditional industries blur, a growing number of companies are choosing a coopetition strategy. So far, efforts to study firms' strategic behavior with regard to coopetition have been centered on public companies with great ownership dispersion. Thus, we have less understanding of the coopetition in the wider context of entrepreneurship (e.g., family firms or small and medium-sized firms). This paper has addressed that shortcoming by associating the unique characteristics of family firms in strategic decisions with the likelihood and stability of coopetition. In general, family firms prioritize the preservation of existing SEWs over pursuing economic profits when making strategic choices, unlike their non-family counterparts. Due to these strategic characteristics, family firms do not favor coopetition. However, such strategic features make them less opportunistic than other types of firms exercising coopetition. We hope that our conceptual framework will serve as a research basis for future studies and help to accumulate much needed knowledge on this increasingly salient topic for strategy research and practice.

\section{References}

Al-Laham, A., Amburgey, T. L., \& Bates, K. (2008). The dynamics of research alliances: Examining the effect of 
alliance experience and partner characteristics on the speed of alliance entry in the biotech industry. British Journal of Management, 19(4), 343-364. https://doi.org/10.1111/j.1467-8551.2007.00553

Andersson, F. W., Johansson, D., Karlsson, J., Lodefalk, M., \& Poldahl, A. (2018). The characteristics of family firms: exploiting information on ownership, kinship, and governance using total population data. Small Business Economics, 51(3), 539-556. https://link.springer.com/article/10.1007/s11187-017-9947-6

Bansal, P. (2005). Evolving sustainably: A longitudinal study of corporate sustainable development. Strategic Management Journal, 26(3), 197-218. https://doi.org/10.1002/smj.441

Barron, J. M., Chulkov, D. V., \& Waddell, G. R. (2011). Top management team turnover, CEO succession type, and strategic change. Journal of Business Research, 64(8), 904-910. https://doi.org/10.1016/j.jbusres.2010.09.004

Baumard P. (2009). An asymmetric perspective on coopetitive strategies. International Journal of Entrepreneurship and Small Business, 8(1), 6-22. https://doi.org/10.1504/JJESB.2009.024102

Bengtsson, M., Raza-Ullah, T., \& Vanyushyn, V. (2016). The coopetition paradox and tension: The moderating role of coopetition capability. Industrial Marketing Management, 53, 19-30. https://doi.org/10.1016/j.indmarman.2015.11.008

Bennedsen, M., Nielsen, K. M., Pérez-González, F., \& Wolfenzon, D. (2007). Inside the family firm: The role of families in succession decisions and performance. The Quarterly Journal of Economics, 122(2), 647-691. https://doi.org/10.1162/qjec.122.2.647

Berrone, P., Cruz, C., \& Gomez-Mejia, L. R. (2012). Socioemotional wealth in family firms: Theoretical dimensions, assessment approaches, and agenda for future research. Family Business Review, 25(3), 258-279. https://doi.org/10.1177/0894486511435355

Berrone, P., Cruz, C., Gomez-Mejia, L. R., \& Larraza-Kintana, M. (2010). Socioemotional wealth and corporate responses to institutional pressures: Do family-controlled firms pollute less?. Administrative Science Quarterly, 55(1), 82-113. https://doi.org/10.2189/asqu.2010.55.1.82

Block, J. (2009). Long-term orientation of family firms: An investigation of $R \& D$ investments, downsizing practices, and executive pay. Springer Science \& Business Media.

Bonel, E., \& Rocco, E. (2007). Coopeting to survive; surviving coopetition. International Studies of Management \& Organization, 37(2), 70-96. https://doi.org/10.2753/IMO0020-8825370204

Bouncken, R. B., Clauß, T., \& Fredrich, V. (2016). Product innovation through coopetition in alliances: Singular or plural governance?. Industrial Marketing Management, 53, 77-90. https://doi.org/10.1016/j.indmarman.2015.11.011

Bouncken, R. B., \& Fredrich, V. (2012). Coopetition: performance implications and management antecedents. $\begin{array}{lllll}\text { International Journal of Innovation } & \text { Management, } & 16(05), & 1250028 .\end{array}$ https://doi.org/10.1142/S1363919612500284

Bouncken, R.B., \& Kraus, S. (2013). Innovation in knowledge-intensive industries: The double-edged sword of coopetition. Journal of Business Research, 66(10), 2060-2070. https://doi.org/10.1016/j.jbusres.2013.02.032

Bouncken, R.B., Gast, J., Kraus, S., \& Bogers, M. (2015). Coopetition: a systematic review, synthesis, and future research directions. Review of Managerial Science, 9(3), 577-601. https://ink.springer.com/article/10.1007/s11846-015-0168-6

Chai, L., Li, J., Clauss, T., \& Tangpong, C. (2019). The influences of interdependence, opportunism and technology uncertainty on interfirm coopetition. Journal of Business \& Industrial Marketing, https://doi.org/10.1108/JBIM-07-2018-0208

Choi, P., Garcia, R., \& Friedrich, C. (2010). The drivers for collective horizontal coopetition: a case study of screwcap initiatives in the international wine industry. International Journal of Strategic Business Alliances, l(3), 271-290. https://doi.org/10.1504/IJSBA.2010.030427

Chrisman, J. J., Chua, J. H., \& Sharma, P. (2005). Trends and directions in the development of a strategic management theory of the family firm. Entrepreneurship Theory and Practice, 29(5), 555-575. https://doi.org/10.1111/j.1540-6520.2005.00098

Chua, J. H., Chrisman, J. J., \& Sharma, P. (1999). Defining the family business by behavior. Entrepreneurship Theory and Practice, 23(4), 19-39. https://doi.org/10.1177/104225879902300402 
Cruz, C., \& Justo, R. (2017). Portfolio entrepreneurship as a mixed gamble: A winning bet for family entrepreneurs in SMEs. Journal of Small Business Management, 55(4), 571-593. https://doi.org/10.1111/jsbm.12341

Czakon, W., Klimas, P., \& Mariani, M. (2020). Behavioral antecedents of coopetition: A synthesis and measurement scale. Long Range Planning, 53(1), 101875. https://doi.org/10.1016/j.lrp.2019.03.001

Czachon, W., \& Mucha-Kuś, K. (2014). Coopetition research landscape-a systematic literature review 1997-2010. Journal of Economics \& Management, 17, 122-150. Retrieved from http://www.ipa-instytut.pl/lib/qrghec/6_Czakon_Mucha-Kus_Rogalski_Coopetition_Research-iqcxo71w.pdf

Das, T. K., \& Kumar, R. (2011). Regulatory focus and opportunism in the alliance development process. Journal of Management, 37(3), 682-708. https://doi.org/10.1177/0149206309356325

De Rond, M., \& Bouchikhi, H. (2004). On the dialectics of strategic alliances. Organization Science, 15(1), 56-69. https://doi.org/10.1287/orsc.1030.0037

Devece, C., Ribeiro-Soriano, D. E., \& Palacios-Marqués, D. (2019). Coopetition as the new trend in inter-firm alliances: literature review and research patterns. Review of Managerial Science, 13(2), 207-226. https://link.springer.com/article/10.1007/s11846-017-0245-0

Feldman, E. R., Amit, R., \& Villalonga, B. (2016). Corporate divestitures and family control. Strategic Management Journal, 37(3), 429-446. https://doi.org/10.1002/smj.2329

Gibb Dyer Jr, W. (2006). Examining the "family effect" on firm performance. Family Business Review, 19(4), 253-273. https://doi.org/10.1111/j.1741-6248.2006.00074

Gnyawali D. R., Madhavan, R., He, J., \& Bengtsson, M. (2016). The competition-cooperation paradox in inter-firm relationships: A conceptual framework. Industrial Marketing Management, 53: 7-18. https://doi.org/10.1016/j.indmarman.2015.11.014

Gnyawali, D. R., \& Park, B. J. R. (2011). Co-opetition between giants: Collaboration with competitors for technological innovation. Research Policy, 40(5), 650-663. https://doi.org/10.1016/j.respol.2011.01.009

Gomez-Mejia, L. R., Campbell, J. T., Martin, G., Hoskisson, R. E., Makri, M., \& Sirmon, D. G. (2014). Socioemotional wealth as a mixed gamble: Revisiting family firm R\&D investments with the behavioral agency model. Entrepreneurship Theory and Practice, 38(6), 1351-1374. https://doi.org/10.1111/etap.12083

Gómez-Mejía, L. R., Haynes, K. T., Núñez-Nickel, M., Jacobson, K. J., \& Moyano-Fuentes, J. (2007). Socioemotional wealth and business risks in family-controlled firms: Evidence from Spanish olive oil mills. Administrative Science Quarterly, 52(1), 106-137. https://doi.org/10.2189/asqu.52.1.106

Gomez-Mejia, L. R., Makri, M., \& Kintana, M. L. (2010). Diversification decisions in family-controlled firms. Journal of Management Studies, 47(2), 223-252. https://doi.org/10.1111/j.1467-6486.2009.00889.x

Gomez-Mejia, L. R., Neacsu, I., \& Martin, G. (2019). CEO risk-taking and socioemotional wealth: The behavioral agency model, family control, and CEO option wealth. Journal of Management, 45(4), 1713-1738. https://doi.org/10.1177/0149206317723711

Greiner, L. E., \& Bhambri, A. (1989). New CEO intervention and dynamics of deliberate strategic change. Strategic Management Journal, 10(S1), 67-86. https://doi.org/10.1002/smj.4250100707

Hergert, M., \& Morris, D. (1988). Trends in international collaborative agreements. Cooperative Strategies in International Business, 99-109.

Hitt, M. A., Ahlstrom, D., Dacin, M. T., Levitas, E., \& Svobodina, L. (2004). The institutional effects on strategic alliance partner selection in transition economies: China vs. Russia. Organization Science, 15(2), 173-185. https://doi.org/10.1287/orsc.1030.0045

Hoffmann, W., Lavie, D., Reuer, J. J., \& Shipilov, A. (2018). The interplay of competition and cooperation. Strategic Management Journal, 39(12), 3033-3052. https://doi.org/10.1002/smj.2965

Hussinger, K., \& Issah, A. B. (2019). Firm acquisitions by family firms: A mixed gamble approach. Family Business Review, 32(4), 354-377. https://doi.org/10.1177/0894486519885544

Kayser, G., \& Wallau, F. (2002). Industrial family businesses in Germany-Situation and future. Family Business Review, 15(2), 111-115. https://doi.org/10.1111/j.1741-6248.2002.00111.x

Kelly, D., \& Amburgey, T. L. (1991). Organizational inertia and momentum: A dynamic model of strategic change. 
Academy of Management Journal, 34(3), 591-612. https://journals.aom.org/doi/10.5465/256407

Kim, J., \& Parkhe, A. (2009). Competing and cooperating similarity in global strategic alliances: an exploratory examination. British Journal of Management, 20(3): 363-376. https://doi.org/10.1111/j.1467-8551.2008.00580.x

King, A., \& Lenox, M. (2002). Exploring the locus of profitable pollution reduction. Management Science, 48(2), 289-299. https://doi.org/10.1287/mnsc.48.2.289.258

Klimas, P. (2016). Organizational culture and coopetition: An exploratory study of the features, models and role in the Polish Aviation Industry. Industrial Marketing Management, 53, 91-102. https://doi.org/10.1016/j.indmarman.2015.11.012

Lascaux, A. (2020). Coopetition and trust: What we know, where to go next. Industrial Marketing Management, 84, 2-18. https://doi.org/10.1016/j.indmarman.2019.05.015

Le Breton-Miller, I., \& Miller, D. (2006). Why do some family businesses out-compete? Governance, long-term orientations, and sustainable capability. Entrepreneurship Theory and Practice, 30(6), 731-746. https://doi.org/10.1111/j.1540-6520.2006.00147.x

Lee, H.U., \& Park, J. H. (2008). The influence of top management team international exposure on international alliance formation. Journal of Management Studies, 45(5), 961-981. https://doi.org/10.1111/j.1467-6486.2008.00772

Lee, J. (2006). Family firm performance: Further evidence. Family Business Review, 19(2), 103-114. https://doi.org/10.1111/j.1741-6248.2006.00060

Lee, K., Makri, M., \& Scandura, T. (2019). The effect of psychological ownership on corporate entrepreneurship: Comparisons between family and nonfamily top management team members. Family Business Review, 32(1), 10-30. https://doi.org/10.1177/0894486518785847

Levinson, H. (1971). Conflicts that plague family businesses. Harvard Business Review, 49(2), 90-98. Retrieved from https://hbr.org/1971/03/conflicts-that-plague-family-businesses

Lumpkin, G. T., Brigham, K. H., \& Moss, T. W. (2010). Long-term orientation: Implications for the entrepreneurial orientation and performance of family businesses. Entrepreneurship \& Regional Development, 22(3-4), 241-264. https://doi.org/10.1080/08985621003726218

Luo, X., Rindfleisch, A., \& Tse, D. K. (2007). Working with rivals: The impact of competitor alliances on financial performance. Journal of Marketing Research, 44(1): 73-83. https://doi.org/10.1509/jmkr.44.1.073

Meade, W., Hyman, M., \& Blank, L. (2009). Promotions as Coopetition in the Soft Drink Industry. Academy of Marketing Studies Journal, 13(1), 105-133. https://doi.org/10.1111/jsbm.12388

Memili, E., Fang, H.C., Koc, B., Yildirim-Öktem, Ö., \& Sonmez, S. (2018). Sustainability practices of family firms: The interplay between family ownership and long-term orientation. Journal of Sustainable Tourism, 26(1), 9-28. https://doi.org/10.1080/09669582.2017.1308371

Moores, K., \& Barrett, M. (2010). Learning family business: Paradoxes and pathways. Bond University Press.

Oum, T. H., Park, J. H., Kim, K., \& Yu, C. (2004). The effect of horizontal alliances on firm productivity and profitability: evidence from the global airline industry. Journal of Business Research, 57(8), 844-853. https://doi.org/10.1016/S0148-2963(02)00484-8

Park, S. H., \& Russo, M. V. (1996). When competition eclipses cooperation: An event history analysis of joint venture failure. Management Science, 42(6), 875-890. https://doi.org/10.1287/mnsc.42.6.875

Park, S. H., \& Ungson, G. R. (2001). Interfirm rivalry and managerial complexity: A conceptual framework of alliance failure. Organization Science, 12(1), 37-53. https://doi.org/10.1287/orsc.12.1.37.10118

Pellegrin-Boucher, E., Le Roy, F., \& Gurău, C. (2013). Coopetitive strategies in the ICT sector: typology and stability. Technology Analysis \& Strategic Management, 25(1), 71-89. https://doi.org/10.1080/09537325.2012.751011

Pounder, P. (2015). Family business insights: an overview of the literature. Journal of Family Business Management. https://doi.org/10.1108/JFBM-10-2014-0023

Raza-Ullah, T., Bengtsson, M., \& Kock, S. (2014). The coopetition paradox and tension in coopetition at multiple levels. Industrial Marketing Management, 43(2), 189-198. https://doi.org/10.1016/j.indmarman.2013.11.001

Ritala, P., Golnam, A., \& Wegmann, A. (2014). Coopetition-based business models: The case of Amazon.com. 
Industrial Marketing Management, 43(2), 236-249. https://doi.org/10.1016/j.indmarman.2013.11.005

Robert, F., Marques, P., \& Le Roy, F. (2009). Coopetition between SMEs: an empirical study of French professional football. International Journal of Entrepreneurship and Small Business, 8(1), 23-43. https://doi.org/10.1504/IJESB.2009.024103

Shukla, P.P., Carney, M., \& Gedajlovic, E. (2014). Economic theories of family firms. The Sage handbook of family business, 100-118.

Strese, S., Meuer, M. W., Flatten, T. C., \& Brettel, M. (2016). Organizational antecedents of cross-functional coopetition: The impact of leadership and organizational structure on cross-functional coopetition. Industrial Marketing Management, 53, 42-55. https://daneshyari.com/article/preview/1027355.pdf

Stockmans, A., Lybaert, N., \& Voordeckers, W. (2010). Socioemotional wealth and earnings management in private family firms. Family Business Review, 23(3), 280-294. https://doi.org/10.1177/0894486510374457

Tidström, A. (2014). Managing tensions in coopetition. Industrial Marketing Management, 43(2), 261-271. https://doi.org/10.1016/j.indmarman.2013.12.001

Timmer, M. P., Inklaar, R., O'Mahony, M., \& Van Ark, B., (2010). Economic growth in Europe: A comparative industry perspective. Cambridge University Press.

Teo, T. S., \& Bhattacherjee, A. (2014). Knowledge transfer and utilization in IT outsourcing partnerships: A preliminary model of antecedents and outcomes. Information \& Management, 51(2), 177-186. https://doi.org/10.1016/j.im.2013.12.001

Vanyushyn, V., Bengtsson, M., Näsholm, M. H., \& Boter, H. (2018). International coopetition for innovation: Are the benefits worth the challenges?. Review of Managerial Science, 12(2), 535-557. https://ink.springer.com/article/10.1007/s11846-017-0272-x

Xue, J., Yuan, H., \& Shi, B. (2016). Investigating partners' opportunistic behavior in joint ventures in China: The role of transaction costs and relational exchanges. Journal of Business Research, 69(12), 6067-6078. https://doi.org/10.1016/j.jbusres.2016.06.011

Zacharia, Z., Plasch, M., Mohan, U., \& Gerschberger, M. (2019). The emerging role of coopetition within inter-firm relationships. The International Journal of Logistics Management. https://doi.org/10.1108/IJLM-02-2018-0021

\section{Copyrights}

Copyright for this article is retained by the author(s), with first publication rights granted to the journal.

This is an open-access article distributed under the terms and conditions of the Creative Commons Attribution license (http://creativecommons.org/licenses/by/4.0/). 